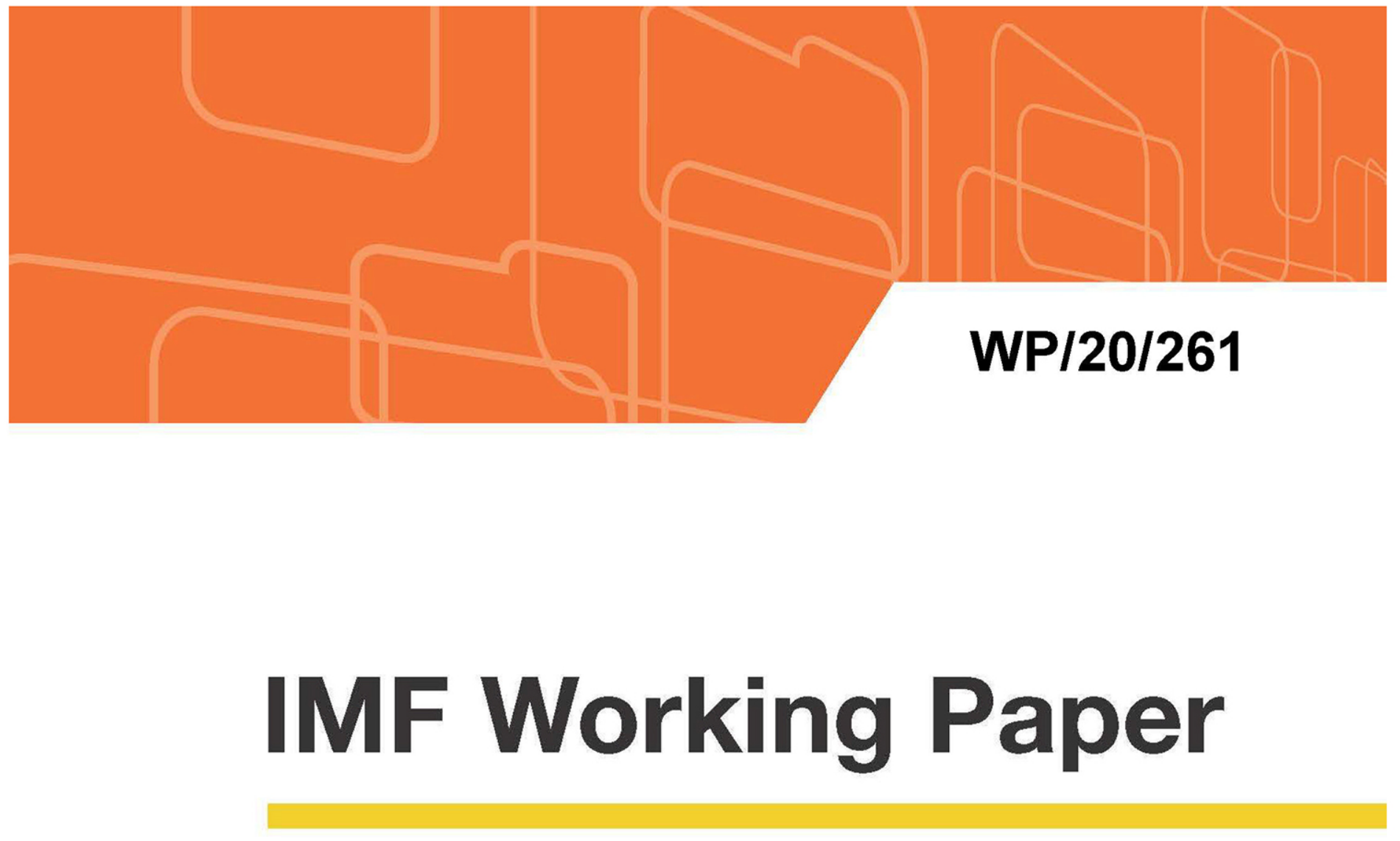

\title{
Public Debt Dynamics and Intra-Year Exchange Rate
} Fluctuations

by Santiago Acosta-Ormaechea

IMF Working Papers describe research in progress by the author(s) and are published to elicit comments and to encourage debate. The views expressed in IMF Working Papers are those of the author(s) and do not necessarily represent the views of the IMF, its Executive Board, or IMF management.

$$
\text { I N T E R N A T I O N A L M O N E T A R Y F U N D }
$$




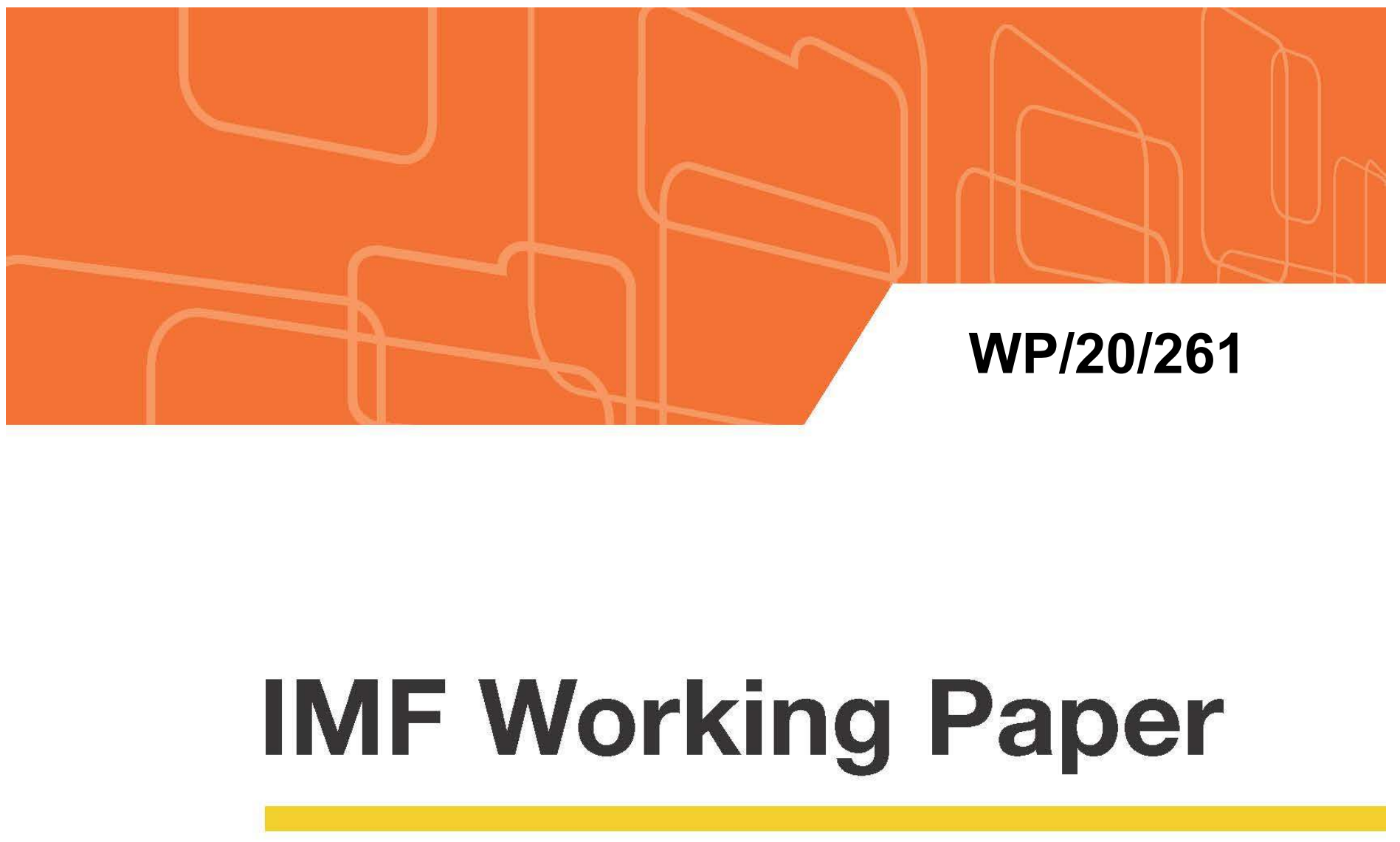

\title{
Public Debt Dynamics and Intra-Year Exchange Rate
} Fluctuations

\author{
by Santiago Acosta-Ormaechea
}

IMF Working Papers describe research in progress by the author(s) and are published to elicit comments and to encourage debate. The views expressed in IMF Working Papers are those of the author(s) and do not necessarily represent the views of the IMF, its Executive Board, or IMF management.

$$
\text { I N T E R N A T I O N A L M O N E T A R Y F U N D }
$$




\title{
IMF Working Paper
}

Institute for Capacity Development

\section{Intra-Year Exchange Rate Fluctuations and Public Debt Dynamics}

Prepared by Santiago Acosta-Ormaechea*

Authorized for distribution by Ralph Chami

November 2020

\section{IMF Working Papers describe research in progress by the author(s) and are published to elicit comments and to encourage debate. The views expressed in IMF Working Papers are those of the author(s) and do not necessarily represent the views of the IMF, its Executive Board, or IMF management.}

\begin{abstract}
The public sector, in carrying out its operations, often incurs foreign currency denominated liabilities and, as such, is exposed to exchange rate fluctuations that could affect the value of public debt to GDP ratios over time. This paper shows that converting foreign currency denominated flows and stocks into local currency using the average and the end-of-period exchange rates, respectively, as envisaged in public finance manuals, gives rise to an identifiable stock-flow adjustment term - due to intra-year exchange rate fluctuations - that affects public debt accumulation. Importantly, the inclusion of this often-ignored stock-flow adjustment term is critical to accurately project public debt levels and any related indicator that could in turn inform about the risk of debt distress. Using a novel dataset covering 82 countries during 2008-19, the paper shows that this stock flow adjustment term is sizable in countries experiencing large exchange rate depreciations, namely above the $99^{\text {th }}$ percentile of the full sample, reaching 1.2 percent of GDP. Interestingly, the measurement of policy-related concepts such as interest rate-growth differentials and debt stabilizing primary balances are also affected by intra-year exchange rate fluctuations, and in non-negligible ways.
\end{abstract}

JEL Classification Numbers: E31, E4, E6, H6.

Keywords: Public debt dynamics; intra-year exchange rate fluctuations; interest rate-growth differential; debt stabilizing primary balance.

Author's E-Mail Address: SAcostaOrmaechea@imf.org

* Institute for Capacity Development, International Monetary Fund, 700 19th St NW, Washington, DC 20431 , USA. I thank Andrew Berg, Ralph Chami, Charles Cohen, Fernando Delgado, Norbert Funke, Maximilien Kaffo, Trevor Lessard, Sandra Lizarazo Ruiz, Leonardo Martinez, Catherine Pattillo, Juan Pradelli, Jorge Restrepo and Manrique Saenz for their comments and suggestions. The conventional disclaimer applies. 


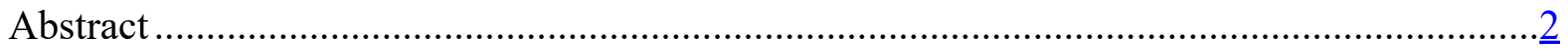

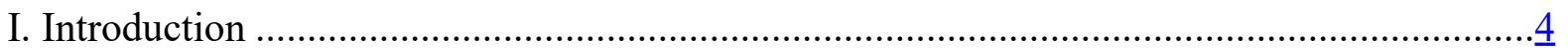

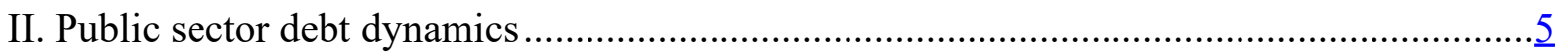

III. Policy-related implications ……………………..................................................

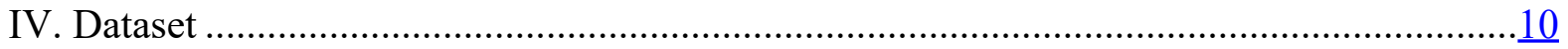

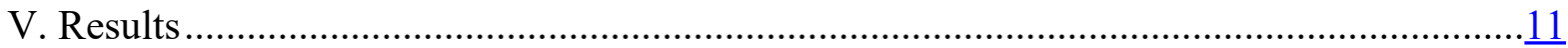

A. Evidence on intra-year exchange rate fluctuations.....................................................11

B. Evidence on interest rate-growth differentials ..............................................................12

C. Evidence on stock-flow adjustment, debt projections and debt-stabilizing primary

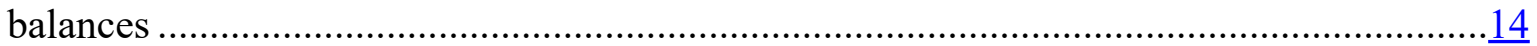

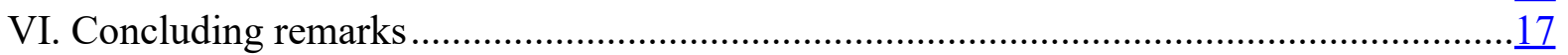

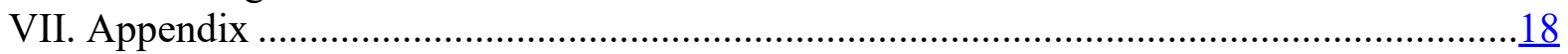

A. Valuation-adjusted nominal effective interest rates ..................................................... 18

B. Decomposition of changes in the public debt to GDP ratio ...........................................19

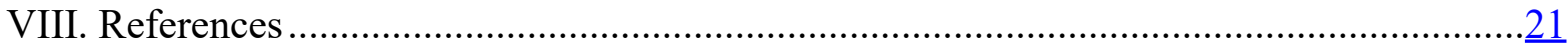

\section{Tables}

Table 1: Descriptive statistics .................................................................................... 10

Table 2: Estimations of interest rate-growth differentials ................................................. 12

Table 3: Estimations of stock-flow adjustment due to intra-year exchange rate changes .......14

Table 4: Estimations of nominal effective interest rates.................................................. $\frac{18}{20}$

Table 5: Debt projections drivers with intra-year exchange rate fluctuations ........................ 20

Table 6: Debt projections and drivers without intra-year exchange rate fluctuations ............. 20

Figures

Figure 1: Ratio of average to end-of-period exchange rates ................................................ 11

Figure 2: Interest rate-growth differentials including intra-year exchange rate fluctuations . $\underline{13}$

Figure 3: Public debt projections and stock-flow adjustment.............................................. $\frac{16}{16}$

Figure 4: Debt-stabilizing primary balance and stock-flow adjustment ................................ $\frac{17}{17}$ 


\section{INTRODUCTION}

Periods of heightened exchange rate volatility can lead to substantial revaluations of the public sector liabilities denominated in foreign currency through increases in the local currency value of flows, e.g., the interest payments on foreign currency denominated debt, and of stocks, e.g., the outstanding amount of foreign currency denominated debt, potentially undermining solvency and/or liquidity considerations in certain countries. ${ }^{1}$

Because of its prominent significance in many emerging and developing economies, where the public sector is often exposed to liabilities denominated in foreign currency, a careful assessment of how exchange rate fluctuations affect flows and stocks is critical for determining how public debt evolves over time. The Excel-based templates used by the IMF to assess public debt sustainability in low-income and market-access countries do this in a precise manner, for instance, by disentangling carefully the currency of denomination and the exchange rates used for the conversion into local currency of the below-the-line or financing components of the public sector over time. ${ }^{2}$

However, the existing literature that assesses above-the-line public debt dynamics with foreign currency denominated liabilities, namely by measuring the public sector debt path over time through the overall fiscal balance (or primary balance and interest bill), has abstracted away from the importance of using different exchange rates to convert foreign currency flows and stocks into local currency (e.g., Croce and Juan-Ramón, 2003; IMF, 2013; Escolano and others, 2017). Since the standard convention in public finance manuals is that debt-related stocks and flows should be converted into local currency using the end-of-period and average exchange rates, respectively (see IMF, 2011, pp. 26-27), ignoring this accounting principle could lead to measurement errors in the projection of public debt in countries exposed to foreign currency liabilities.

The objective of this paper is to lay out the basic above-the-line public sector debt accumulation equation when a portion of debt is denominated in foreign currency, but incorporating the fact that the average and the end-of-period exchange rates should be used simultaneously for the conversion of flows and stocks into the local currency. This gives rise to a stock-flow adjustment term stemming from intra-year exchange rate valuation effects, which becomes an additional and identifiable component that affects the evolution of public debt. Importantly, understanding carefully public debt dynamics above-the-line, permits to make public debt rules easily operationalizable by quantifying, for instance, what would be the relevant interest rate-growth differential that affects debt changes and/or the primary balance that would be needed to stabilize debt at the previous period level. Moreover, the inclusion of this often-ignored stock-flow adjustment term is critical to accurately project public debt levels and any associated indicator that could in turn inform about the risk of debt distress.

\footnotetext{
${ }^{1}$ Similar considerations are relevant when assessing the foreign currency liabilities of the private sector. However, since the focus of the paper is only on public sector debt, these are not evaluated here.

${ }^{2}$ See IMF $(2013,2018)$ for details on the so-called MAC DSA and LIC DSF frameworks.
} 
To evaluate in which cases intra-year exchange rate fluctuations have been relevant from a quantitative standpoint, a novel dataset covering 82 countries during the period 2008-19 is assembled. With this dataset in hand, the paper then evaluates how this type of exchange rate valuation effect affects the interest rate-growth differential, public debt projections and the debt-stabilizing primary balance.

The paper shows that, while not sizeable on average, the stock-flow adjustment term arising from intra-year exchange rate fluctuations was large in countries that experienced significant nominal depreciations. While the full sample mean of this term is 0.02 percent of GDP, it reaches 0.2 and 1.2 percent of GDP in those countries that went through large nominal depreciations, namely above the $90^{\text {th }}$ and $99^{\text {th }}$ percentile of the full sample, respectively. ${ }^{3}$ Next, for the full sample, the interest rate-growth differential is reduced on average about 0.04 percentage points once intra-year exchange rate fluctuations are accounted for, but this differential is 0.6 percentage points lower in countries that experienced depreciations above the $99^{\text {th }}$ percentile of the full sample. In those countries, estimations suggest that in the year of the large nominal depreciation debt projections could have been underestimated by about 0.9 percentage points of GDP while the debt-stabilizing primary balances could have been overestimated by about 1.5 percentage points of GDP, if intra-year exchange rate valuation effects were not properly accounted for.

The rest of the paper is organized as follows. Section II introduces the basic above-the-line public debt accumulation equation when intra-year exchange rate fluctuations are considered. Section III then turns into a discussion of the analytics to assess policy-relevant implications. Section IV introduces a novel dataset to quantify the relevance of intra-year exchange rate valuation effects, while Section V summarizes the main quantitative results. Finally, Section VI concludes.

\section{PUBLIC SECTOR DEBT DYNAMICS}

Existing papers that assess public debt dynamics considering that public debt can either be denominated in local or in foreign currency, as it is observed in many emerging and developing countries, specify a dynamic equation for gross public debt in nominal terms as follows (e.g., Escolano and others, 2017; IMF, 2013):

$$
D_{t}=\left(e_{t}^{e o p} D_{t-1}^{f}+D_{t-1}^{d}\right)+e_{t}^{e o p} i_{t}^{f} D_{t-1}^{f}+i_{t}^{d} D_{t-1}^{d}-P B_{t}+O F_{t}
$$

where $D_{t}\left(\equiv e_{t}^{e o p} D_{t}^{f}+D_{t}^{d}\right)$ refers to the total stock of gross public debt measured in local currency at the end of period $t ; D_{t}^{f}$ and $D_{t}^{d}$ are public debt denominated in foreign and in local currency, respectively, at the end of period $t$; $e_{t}^{e o p}$ indicates the end-of-period exchange rate (local currency per unit of the foreign currency) at period $t ; i_{t}^{f}$ and $i_{t}^{d}$ are the effective

\footnotetext{
${ }^{3}$ Currently, the IMF MAC DSA and IMF/WB LIC DSF frameworks allocate intra-year exchange rate valuation effects as part of a 'residual' term that is shown in output tables. Given that these are flows that can be identified, in principle these valuation effects can be stripped out from that 'residual' to be presented as a standalone component the same way as any other identifiable debt-creating flow.
} 
nominal interest rates on foreign and local currency denominated debt during period $t$, respectively; ${ }^{4,5}$ and $P B_{t}$ and $O F_{t}$ refer to the primary balance (i.e., primary government revenue minus primary government expenditure) and other net debt-creating flows (e.g., realization of contingent liabilities, privatizations, use/build-up of liquid assets) that take place during period $t^{6,7}$

This specification, however, abstracts away from the fact that the flow interest payment on foreign currency debt, $i_{t}^{f} D_{t-1}^{f}$, is paid throughout the year, and as such it should be converted to local currency using the average, instead of the end-of-period, exchange rate (see IMF, 2011, p. 26-27). Acknowledging this, (1) could be re-written as:

$$
D_{t}=\left(e_{t}^{e o p} D_{t-1}^{f}+D_{t-1}^{d}\right)+e_{t}^{a v g} i_{t}^{f} D_{t-1}^{f}+i_{t}^{d} D_{t-1}^{d}-P B_{t}+O F_{t}+S F_{t}
$$

When comparing (1) and (2) it is apparent that besides the use of the average exchange rate for the foreign currency interest bill, an additional term, $S F_{t}$, is included. This is a stock-flow adjustment element that takes place during period $t$, whose role is to 'adjust' for the different exchange rates used to convert flows and stocks from the foreign and into the local currency, such that (2) holds. Although $S F_{t}$ is taken as exogenous in (2), it should be endogenized to properly measure the evolution of public debt over time in local currency.

Defining $S F_{t}=\left(e_{t}^{e o p}-e_{t}^{a v g}\right)\left(D_{t}^{f}-D_{t-1}^{f}\right)$, it is now possible to obtain the analytical term that revalues foreign currency flows from the average and to the end-of period exchange rate, to ensure that public debt measured in local currency is properly accounted for. Then, (2) takes the form,

$$
\begin{gathered}
D_{t}=\left(e_{t}^{e o p} D_{t-1}^{f}+D_{t-1}^{d}\right)+e_{t}^{a v g} i_{t}^{f} D_{t-1}^{f}+i_{t}^{d} D_{t-1}^{d}-P B_{t}+O F_{t} \\
+\left(e_{t}^{e o p}-e_{t}^{a v g}\right)\left(D_{t}^{f}-D_{t-1}^{f}\right) .
\end{gathered}
$$

\footnotetext{
${ }^{4}$ Note that the effective interest rates $i_{t}^{f}$ and $i_{t}^{d}$ may subsume the effects of interest payments on existing debt and on $n e w$ debt issuances that accrue interest during period $t$.

${ }^{5}$ Observe that the effective interest rate on foreign currency debt is given by $i_{t}^{f}=\frac{I_{t}^{f}}{D_{t-1}^{f}}$, where $I_{t}^{f}$ denote the interest payment on foreign currency debt accruing during period $t$. Since both $I_{t}^{f}$ and $D_{t-1}^{f}$ are expressed in the foreign currency, $i_{t}^{f}$ is not affected by exchange rate fluctuations.

${ }^{6}$ Strictly speaking, other net debt-creating flows likely involve financing components of the budget. In that sense, neither (1) nor (2) is a 'pure' above-the-line relation. However, including this term is relevant to determine accurately the key drivers of gross public debt over time (see, e.g., IMF, 2013).

${ }^{7}$ IMF (2013) also includes a residual term in (1) to ensure that the accounting identity that determines public debt holds. However, since there is no guidance provided on how such residual can be decomposed into identifiable terms to project public debt, this term is excluded from (1).
} 
Note that (1) and (3) are identical if $e_{t}^{a v g} / e_{t}^{e o p}=1$ and/or if the change in foreign currency borrowing is such that $D_{t}^{f}-D_{t-1}^{f}=i_{t}^{f} D_{t-1}^{f}$. However, the two equations may differ if intrayear exchange rate fluctuations are present, namely if $e_{t}^{a v g} / e_{t}^{e o p} \neq 1$, as it would occur in countries with foreign currency debt experiencing exchange rate appreciations or depreciations throughout the year. ${ }^{8}$

To better understand the implications of intra-year exchange rate valuation effects, it is useful to define the share of foreign currency denominated debt in total debt as $\alpha_{t}=e_{t}^{e o p} D_{t}^{f} / D_{t}$ and the rate of change of the end-of-period exchange rate as $\varepsilon_{t}^{e o p}=e_{t}^{e o p} / e_{t-1}^{e o p}-1$. In addition, it is also useful to introduce the valuation-adjusted average nominal effective interest rate (that is, the overall effective interest rate paid by the government including capital gains/losses on the principal due to exchange rate fluctuations) as:

$$
i_{t}^{i y x r}=\left[\alpha_{t-1}\left(1+i_{t}^{f}\right)\left(1+\varepsilon_{t}^{e o p}\right) e_{t}^{a v g} / e_{t}^{e o p}+\left(1-\alpha_{t-1}\right)\left(1+i_{t}^{d}\right)\right]\left(1-\alpha_{t} \gamma_{t}\right)^{-1}-1,
$$

where $\gamma_{t} \equiv\left(1-e_{t}^{a v g} / e_{t}^{e o p}\right)$ is a wedge between the end-of-period and the average exchange rates measured as a fraction of the former. Note that (4) simplifies, when assuming $e_{t}^{a v g} / e_{t}^{e o p}=1$, to

$$
i_{t}^{n o \_i y x r}=\alpha_{t-1}\left(1+i_{t}^{f}\right)\left(1+\varepsilon_{t}^{e o p}\right)+\left(1-\alpha_{t-1}\right)\left(1+i_{t}^{d}\right)-1 .
$$

From here onwards, variables with superscripts iyxr and no_iyxr indicate that intra-year exchange rate fluctuations are and are not included, respectively. Note that (4) is the relevant net effective cost of public debt when $e_{t}^{a v g} / e_{t}^{e o p} \neq 1 .{ }^{9}$ After some rearrangement and using

\footnotetext{
${ }^{8}$ To better understand why (3) properly computes debt levels, and why this equation also requires a stock-flow adjustment term, consider a simple case where $D_{t}^{d}=D_{t-1}^{d}=O F_{t}=P B_{t}=0$. Since there is only foreign currency borrowing, it follows that the total stock of public debt measured in foreign currency is $D_{t}^{f}=D_{t-1}^{f}+$ $i_{t}^{f} D_{t-1}^{f}$. Assuming that $D_{t-1}^{f}=U S \$ 100$ and that $i_{t}^{f}=0.1$, it follows that $D_{t}^{f}=U S \$ 110$ at the end of period $t$. If the end-of-period and the average exchange rates are say $3 \mathrm{LC} \$ \mathrm{US} \$$ and $2 \mathrm{LC} \$ / \mathrm{US} \$$, respectively, then the total stock of debt at the end of period texpressed in local currency is $D_{t}=e_{t}^{e o p} D_{t}^{f}=L C \$ 330$. It can be easily checked that this total can be equivalently obtained from (3) as $D_{t}=e_{t}^{e o p} D_{t-1}^{f}+e_{t}^{a v g} i_{t}^{f} D_{t-1}^{f}+$ $\left(e_{t}^{e o p}-e_{t}^{a v g}\right)\left(D_{t}^{f}-D_{t-1}^{f}\right)$. Moreover, suppose now that $P B_{t}=\mathrm{LC} \$ 20$ (instead of 0 ), namely a primary balance surplus that exactly covers the flow interest payments on foreign currency debt. The total stock of debt $D_{t}$ at the end of period t expressed in local currency now becomes $D_{t}=L C \$ 300$ (i.e., the total stock of foreign currency debt does not change between periods), an amount which can be exactly obtained again using (3). However, when using (1) instead, the stock of debt would have been overestimated at $L C \$ 310$.

${ }^{9}$ It is useful to briefly outline how to 'match' the data obtained from fiscal accounts into this valuation-adjusted nominal effective interest rate. From fiscal statements one might be able to obtain the total interest bill paid for local and foreign currency debt altogether, but likely already converted into local currency (i.e., $I n t_{t}$ ). The total stock of debt (i.e., $D_{t}$ ), is also likely to be reported in local currency. Thus, the effective nominal interest rate from fiscal accounts is equal to $i_{t}^{f i s c}=\frac{I n t_{t}}{D_{t-1}}=\alpha_{t-1} i_{t}^{f}\left(1+\varepsilon_{t}^{e o p}\right) e_{t}^{a v g} / e_{t}^{e o p}+\left(1-\alpha_{t-1}\right) i_{t}^{d}$. It then follows that $i_{t}^{i y x r}=\left[i_{t}^{f i s c}+\alpha_{t-1}\left(1+\varepsilon_{t}^{e o p}\right) e_{t}^{a v g} / e_{t}^{e o}+\left(1-\alpha_{t-1}\right)\right]\left(1-\alpha_{t} \gamma_{t}\right)^{-1}-1$
} 
(4) and (5), it is then possible to express the change in public debt as a share of nominal GDP at time $t\left(=P_{t} Y_{t}\right)$ with and without the inclusion of intra-year exchange rate effects as follows,

$$
d_{t}^{i y x r}-d_{t-1}^{i y x r}=\left[\frac{1+i_{t}^{i y x r}}{\left(1+g_{t}\right)\left(1+\pi_{t}\right)}-1\right] d_{t-1}^{i y x r}+\frac{1}{1-\alpha_{t} \gamma_{t}}\left(-p b_{t}+o f_{t}\right)
$$

and

$$
d_{t}^{n o \_i y x r}-d_{t-1}^{n o-i y x r}=\left[\frac{1+i_{t}^{n o-i y x r}}{\left(1+g_{t}\right)\left(1+\pi_{t}\right)}-1\right] d_{t-1}^{n o-i y x r}-p b_{t}+o f_{t} .
$$

As usual, lower-case variables refer to shares of GDP; $d_{t}^{i y x r}$ is the debt-to-GDP ratio when intra-year exchange rate fluctuations are considered (i.e., derived from (3)); $d_{t}^{\text {no iyxr }}$ refers to the debt-to-GDP ratio when intra-year exchange rate fluctuations are not considered (i.e., derived from (1)); $g_{t}$ is the real GDP growth rate at time $t$; and $\pi_{t}$ is domestic inflation at time $t$ as measured by the GDP deflator. ${ }^{10}$

It follows that (6) and (7) are identical when $e_{t}^{a v g} / e_{t}^{e o p}=1$, yet they could differ if $e_{t}^{a v g} / e_{t}^{e o p} \neq 1$. Before turning to a quantitative assessment, it is useful to discuss the analytics of two policy-related implications.

\section{POLICY-RELATED IMPLICATIONS}

The interest rate-growth differential (IRGD) and the debt-stabilizing primary balance (DSPB) at the previous-period debt level can now be easily computed from either (6) or (7). The IRGD provides an indicator of how public debt would change over time (as a share of GDP) absent policy actions, and is a key determinant of the 'automatic-debt-dynamics' portion of debt changes as identified in (6) and (7). The DSPB summarizes what would be the appropriate primary balance to stabilize public debt at its previous-period level. From (6) and (7) the IRGD will also depend on whether intra-year exchange rate fluctuations are considered. Formally, the IRGD is given by

$$
\operatorname{IRGD} D_{t}^{i y x r}=\frac{1+i_{t}^{i y x r}}{\left(1+g_{t}\right)\left(1+\pi_{t}\right)}-1,
$$

and

$$
I R G D_{t}^{\text {no } i y x r}=\frac{1+i_{t}^{\text {no_iyxr }}}{\left(1+g_{t}\right)\left(1+\pi_{t}\right)}-1
$$

${ }^{10}$ To obtain (6) it is helpful to realize that the stock-flow adjustment term as a share of GDP is: $s f_{t}=\frac{S F_{t}}{Y_{t} P_{t}}=$ $\frac{\left(e_{t}^{e o p}-e_{t}^{a v g}\right)\left(D_{t}^{f}-D_{t-1}^{f}\right)}{Y_{t} P_{t}}=\frac{\left(e_{t}^{e o p}-e_{t}^{a v g}\right)}{e_{t}^{e o p}}\left(\alpha_{t} d_{t}-\alpha_{t-1} d_{t-1} \frac{\left(1+\varepsilon_{t}^{e o p}\right)}{\left(1+g_{t}\right)\left(1+\pi_{t}\right)}\right)$. 
The expression for IRGD $D_{t}^{\text {no_iyxr }}$ in (9) is the same as that of Escolano and others (2017, p. 183). However, this does not fully account for exchange rate valuation effects the same way as $I R G D_{t}^{i y x r}$ in (8) does. Next, by setting $d_{t}^{i y x r}-d_{t-1}^{i y x r}=0$ and $d_{t}^{n o-i y x r}-d_{t-1}^{n o-i y x r}=0$ in (6) and (7), the debt-stabilizing primary balances (at the previous-period debt levels) are given by,

$$
\operatorname{DSPB}_{t}^{i y x r}=\left[\frac{1+i_{t}^{i y x r}}{\left(1+g_{t}\right)\left(1+\pi_{t}\right)}-1\right]\left(1-\alpha_{t} \gamma_{t}\right) d_{t-1}^{i y x r}+o f_{t}
$$

and

$$
D S P B_{t}^{n o_{-} i y x r}=\left[\frac{1+i_{t}^{n o_{i y x r}}}{\left(1+g_{t}\right)\left(1+\pi_{t}\right)}-1\right] d_{t-1}^{n o_{i} i y x r}+o f_{t} .
$$

As with the IRGD, (10) and (11) are identical if $e_{t}^{a v g} / e_{t}^{e o p}=1$, yet they would differ if $e_{t}^{a v g} / e_{t}^{e o p} \neq 1$

To quantitatively illustrate the implications of these relations, consider an economy where in a given year $t \alpha_{t}=0.6, i_{t}^{f}=i_{t}^{d}=0.05, g_{t}=\pi_{t}=0.03, p b_{t}=-0.1$ and $o f_{t}=0.05$, and that these figures are expected to remain the same in year $t+1$, with the exception of $\alpha_{t+1}$, which is expected to increase to $\alpha_{t+1}=0.7$. Assume also that in period $t e_{t}^{a v g}=1.25$ $\mathrm{LC} / \mathrm{US} \$$ and $e_{t}^{e o p}=1.50 \mathrm{LC} \$ \mathrm{US} \$$, but that in period $t+1$ it is expected that $e_{t+1}^{a v g}=2.25$ $\mathrm{LC} \$ / \mathrm{US} \$$ and $e_{t+1}^{e o p}=3.00 \mathrm{LC} \$ / \mathrm{US} \$$. That is, a large nominal exchange rate depreciation is anticipated for the coming year, leading to an increase in the gap between the average and the end-of-period exchange rates.

The valuation-adjusted nominal effective interest rates can be calculated using (4) and (5), yielding $i_{t+1}^{i y x r}=65.5$ and $i_{t+1}^{n o \_i y x r}=68.0$ percent. That is, the relevant effective rate on debt would be overestimated if intra-year exchange rate fluctuations were not properly accounted for. A similar pattern can be observed for the IRGD, yielding $I R G D_{t+1}^{i y x r}=56.0$ and $I R G D_{t+1}^{\text {no ilyxr }}=58.4$ percent. Further, if the debt-to-GDP ratio in period $t$ is assumed to be 50 percent (i.e., $d_{t-1}^{i y x r}=d_{t-1}^{\text {no_iyxr }}=0.5$ ), then from (6) and (7) debt projections would be $d_{t}^{i y x r}=96.2$ and $d_{t}^{\text {no_iyxr }}=94.2$ percent of GDP. That is, the lower overall cost of debt assumed with intra-year exchange rate fluctuations is more than compensated by the relatively larger contribution of the primary deficit and other net debt-creating flows to the evolution of public debt, leading to an overall higher public debt projection. ${ }^{11}$ The debtstabilizing primary balance needed to keep the debt ratio at 50 percent of GDP can be obtained from (10) and (11), yielding $D S P B_{t+1}^{i y x r}=28.1$ and $D S P B_{t+1}^{n o-i y x r}=34.2$ percent of GDP. Interestingly, ignoring intra-year valuation effects would have led to an

${ }^{11}$ Observe from (6) the contribution of the primary balance and other net debt-creating flows in explaining public debt changes, when including intra-year valuation effects, is augmented by the term $\frac{1}{1-\alpha_{t} \gamma_{t}}=1.2$ under this parameterization. 
underestimation of debt levels and an overestimation of the primary balance needed to stabilize debt at the previous-period level. The direction of results in the simulation can change significantly depending on whether the exchange rate is expected to appreciate or depreciate, whether the share of foreign currency debt in total debt, $\alpha_{t}$, is expected to change between periods, and on the evolution of the primary balance and other net debt-creating flows. But under plausible parameterizations differences between the average and the end-ofperiod exchange rates would have relevant policy implications.

The remaining of the paper evaluates the relevance of intra-year exchange rate fluctuations in the observed data, and whether public debt projections and the associated concepts of IRGD and DSPB are affected by differences between the average and the end-of-period exchange rates, namely if $e_{t}^{a v g} / e_{t}^{e o p} \neq 1$.

\section{Dataset}

To evaluate the empirical relevance of intra-year exchange rate valuation effects, a new dataset is assembled using data from the IMF's World Economic Outlook (WEO), April 2020 release. In addition, the dataset is augmented with the IMF's MAC DSA dataset to include a decomposition of gross public debt and effective interest rates into their local and foreign currency components. Overall, the dataset covers a sample of 82 advanced and emerging economies that reported a positive share of public debt denominated in foreign currency out of total gross public debt during the period 2008-19 (Table 1). ${ }^{12,13}$

Table 1: Descriptive statistics

(sample 2008-19, in percent, unless otherwise noted)

\begin{tabular}{lccccc}
\hline Variables & Obs & Mean & $\begin{array}{c}\text { Std } \\
\text { Dev }\end{array}$ & Min & Max \\
\hline Total gross public debt / GDP & 574 & 51.54 & 27.55 & 7.60 & 172.18 \\
Gross public debt in FX / total debt & 574 & 38.78 & 24.12 & 0.03 & 97.98 \\
Gross public debt in LC / total debt & 574 & 61.22 & 24.12 & 2.02 & 99.97 \\
Eff. nominal interest rate on FX debt & 574 & 3.91 & 2.35 & -1.04 & 30.91 \\
Eff. nominal interest rate on LC debt & 574 & 6.50 & 3.21 & -1.93 & 19.17 \\
Real GDP growth & 574 & 3.13 & 2.80 & -9.77 & 11.34 \\
GDP deflator inflation & 574 & 4.59 & 6.49 & -20.19 & 51.51 \\
Primary balance / GDP & 574 & -0.80 & 3.42 & -16.10 & 16.38 \\
Nominal exchange rate depreciation & 574 & 4.42 & 12.40 & -17.30 & 104.14 \\
Avg to end-of-period XR (ratio) & 574 & 0.98 & 0.05 & 0.68 & 1.11 \\
\hline
\end{tabular}

Source: Author's calculations based on IMF's WEO and MAC DSA databases.

\footnotetext{
12 Unfortunately, a dataset on the currency of denomination of gross public debt and the associated effective nominal interest rates for low-income countries is not readily available, thereby restricting the sample of countries used in this analysis to market-access countries as defined by IMF (2013).

${ }^{13}$ The final sample used in the analysis is restricted relative to the original one that has been created, since only those country/year observations with non-missing values for effective interest rates in local and foreign currencies are considered. Importantly, however, there is no apparent bias in terms of which country/year observations are disregarded due to lack of available data on effective interest rates on local and foreign currency debt.
} 
From Table 1, it follows that for the 82 countries of this dataset, on average, about 39 percent of total debt is denominated in foreign currency (roughly about 20 percent of GDP). As expected, effective interest rates in foreign currency are below effective rates in local currency, yet this difference is not fully accounted for realized exchange rate depreciations. Next, on average an annual primary deficit is observed at 0.8 percent of GDP for the full sample, and the average nominal GDP growth is about 7.7 percent annually. Finally, on average the ratio of the average to the end-of-period exchange rate is slightly below 1 at 0.98 (consistent with a trend depreciation over time), but with significant differences between the minimum (0.68) and the maximum (1.11) values of the sample. The next section evaluates the quantitative relevance of the previous analysis using this dataset.

\section{REsults}

\section{A. Evidence on intra-year exchange rate fluctuations}

To underscore the relevance of intra-year exchange rate fluctuations, Figure 1 plots the ratio between the average and the end-of-period exchange rates for the subset of the sample that experienced nominal depreciations below the $10^{\text {th }}$ and above the $90^{\text {th }}$ percentiles of the full sample. The objective is to assess if in those cases the ratio between the average and the endof-period exchange rates can be substantially different from the full sample mean (0.98), a fact that may suggest the need for a careful assessment of the exchange rates used to convert flows and stocks to local currency at the time of undertaking public debt projections.

Figure 1: Ratio of average to end-of-period exchange rates
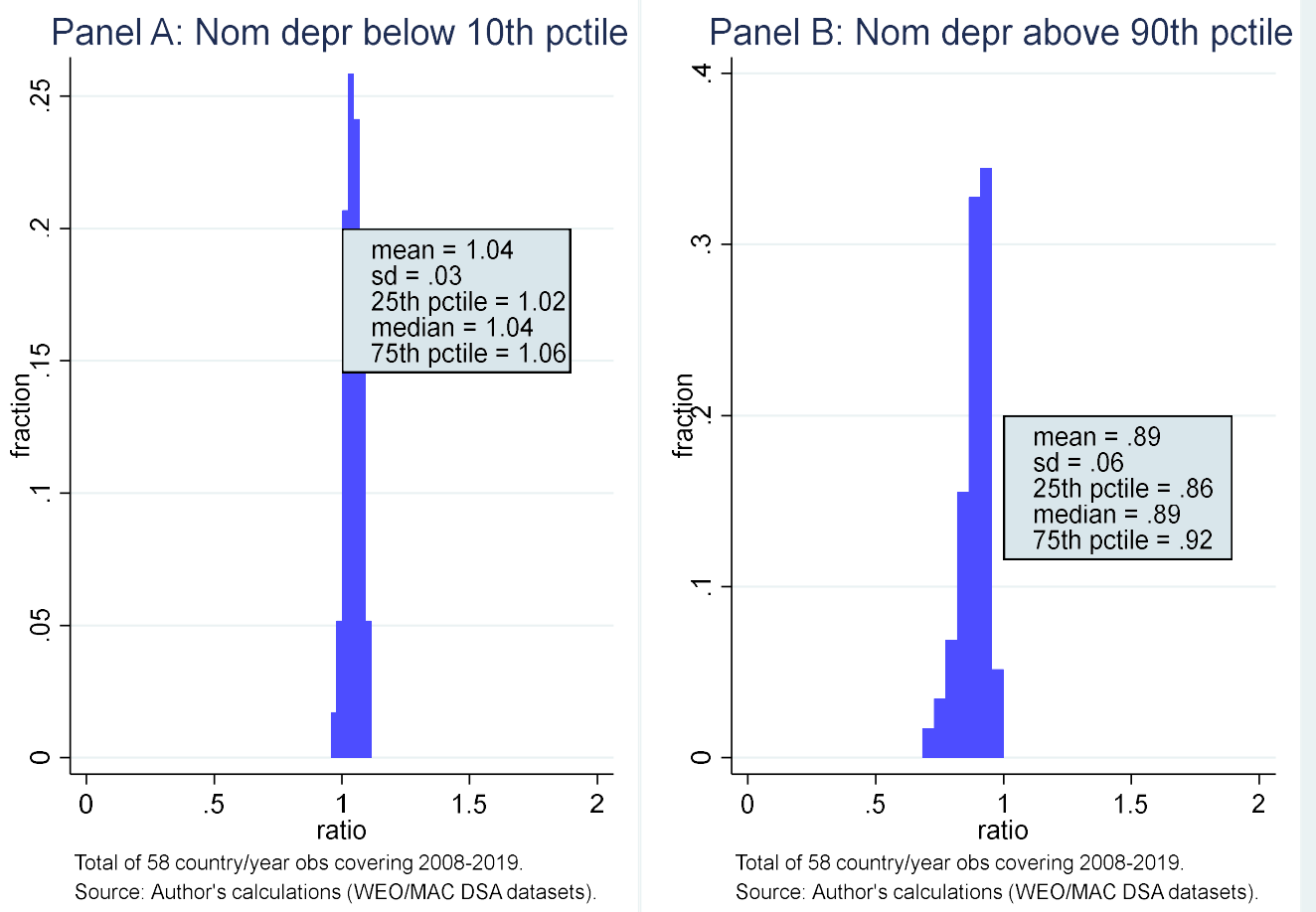

Panel A considers all cases where the exchange rate depreciated below the $10^{\text {th }}$ percentile of the full sample, providing a total of 58 country/year observations. Panel B, instead, restricts 
the sample to those country/year observations with nominal exchange rate depreciations above the $90^{\text {th }}$ percentile of the full sample, bringing also a total of 58 observations. Although for the full sample the mean of the exchange rate ratio is 0.98 , those countries experiencing 'significant' nominal appreciations/depreciations during the 2008-19 period had important deviations from that sample mean, with average ratios at 1.04 and 0.89 , respectively. ${ }^{14}$ This difference can lead to quantitatively relevant differences in debt projections over time, as discussed below.

\section{B. Evidence on interest rate-growth differentials}

From (8) and (9) the interest rate-growth differentials can now be computed for the full sample, and by country groups. To the extent there are differences between the average and the end-of-period exchange rates, the so-called 'automatic debt dynamics' portion of the debt accumulation equation will differ, and so will debt projections over time.

Table 2: Estimations of interest rate-growth differentials (sample 2008-19, in percentage points)

\begin{tabular}{|c|c|c|c|c|c|}
\hline & \multirow{2}{*}{$\begin{array}{c}\text { No of } \\
\text { countries }\end{array}$} & \multirow[t]{2}{*}{ Obs } & \multirow{2}{*}{$\frac{\text { IRGD_iyxr }}{\text { Mean }}$} & \multirow{2}{*}{$\begin{array}{c}\text { IRGD_no_iyxr } \\
\text { Mean }\end{array}$} & \multirow{2}{*}{$\begin{array}{l}\begin{array}{l}\text { Nom } \\
\text { growth }\end{array} \\
\text { Mean }\end{array}$} \\
\hline & & & & & \\
\hline HICs & 28 & 161 & 0.80 & 0.80 & 4.66 \\
\hline UMICs & 35 & 231 & 0.03 & 0.09 & 8.09 \\
\hline LMICs & 19 & 182 & -2.04 & -2.00 & 10.30 \\
\hline Full sample & 82 & 574 & -0.41 & -0.38 & 7.83 \\
\hline Nom depr below 1st pctile & 5 & 5 & -6.22 & -6.22 & 6.23 \\
\hline Nom depr below 10th pctile & 35 & 57 & -5.30 & -5.35 & 8.20 \\
\hline Nom depr above 90th pctile & 29 & 57 & 6.08 & 6.28 & 12.84 \\
\hline Nom depr above 99th pctile & 5 & 5 & 15.28 & 15.84 & 24.98 \\
\hline
\end{tabular}

Note: Countries' group income classification based on that of World Bank as of 2017. IRGD computed using (8) and (9) on a country/year basis.

Source: Author's calculations based on IMF's WEO and MAC DSA datasets.

From Table 2, intra-year exchange rate fluctuations are unlikely to be a major source of discrepancies in the estimation of the IRGD for the 'average' country. In fact, the IRGD seems to be only around 0.04 percentage points lower on average once intra-year exchange rate fluctuations are considered. However, there is significant heterogeneity across country groups. For instance, the IRGD is about 0.20 or even 0.57 percentage points lower once intra-year exchange rate fluctuations are accounted for in those countries that experienced episodes of significant nominal exchange depreciations (Table 2). Consistent with this finding, Appendix A shows that valuation-adjusted nominal effective interest rates tend to be lower once intra-year exchange rate differences are accounted for, thereby explaining this observed pattern with the IRGD. Overall, accounting for intra-year exchange rate

\footnotetext{
14 The mean exchange rate ratio is 1.09 and 0.78 if the sample is instead restricted to those country/year observations with nominal exchange rate depreciations below the $1^{\text {st }}$ and above the $99^{\text {th }}$ percentiles of the full sample, respectively.
} 
fluctuations appears to reduce the IRGD relative to a case in which these valuation effects are ignored. ${ }^{15}$

Although the IRGD for the full sample is negative, there seems to be an upward trend over time once the sample is divided between the 2010-14 and 2015-19 subperiods. To see this, the IRGD is estimated using (8) and shown in Figure 2. A similar pattern is noted in Mauro and Zhou (2020) by comparing the post-1980 and post-Global Financial Crisis periods.

Figure 2: Interest rate-growth differentials including intra-year exchange rate fluctuations
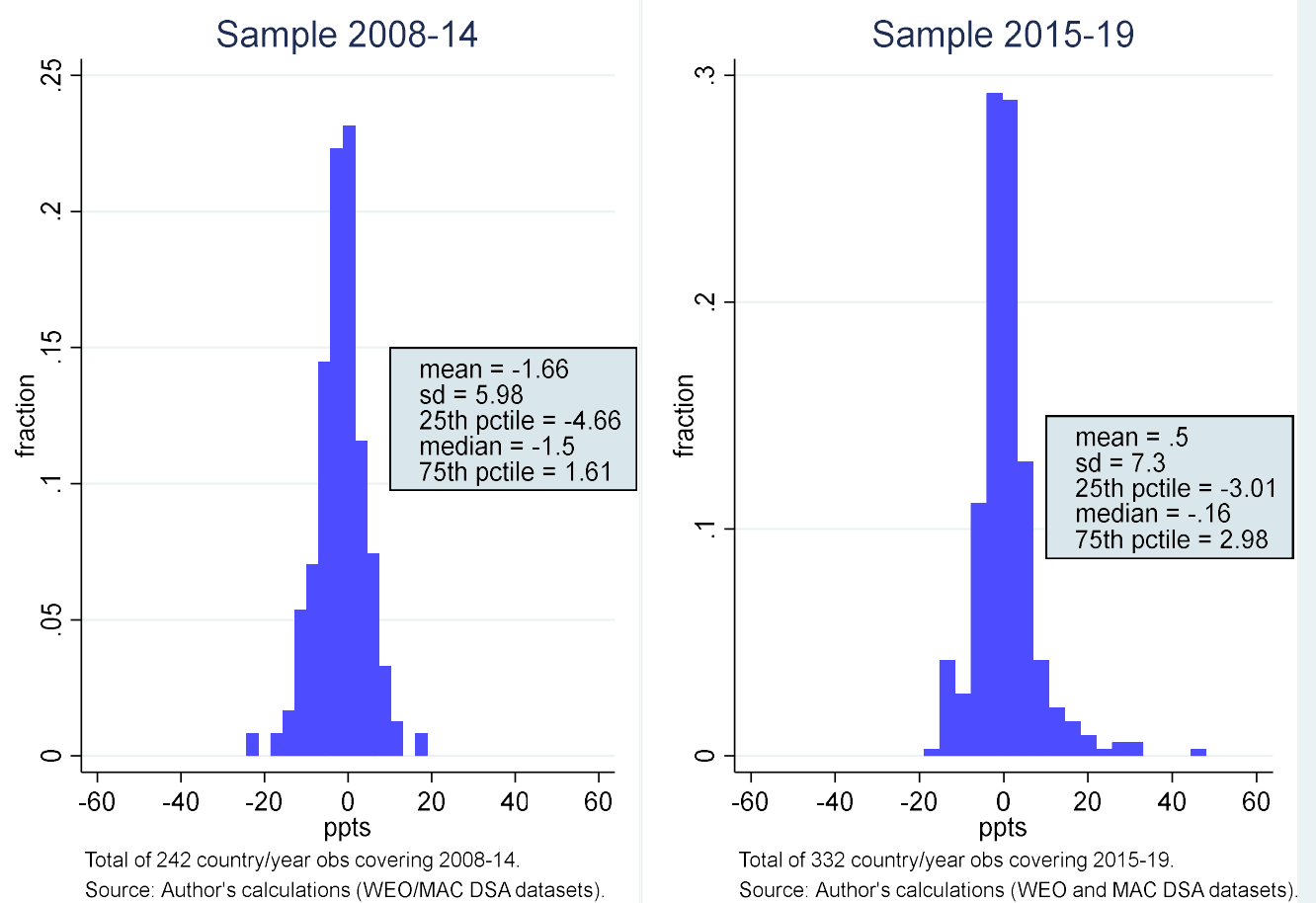

More stable average inflation rates, and possibly better fiscal reporting in a context of deeper financial integration and fewer sources of financial repression, could be contributing to this trend. In the case of advanced countries, efforts to normalize monetary policy amid improved growth prospects in the aftermath of the global financial crisis, may have also contributed to this observed tendency. ${ }^{16}$ In any event, given that intra-year exchange rate fluctuations could affect debt projections in a quantitatively relevant way through interest rate-growth

\footnotetext{
${ }^{15}$ It is worth observing that there is a tendency for $i_{t}^{i y x r}<i_{t}^{\text {no } i y x r}$ if the exchange rate depreciates over time. To see this compare (4) and (5) assuming $\alpha_{t}$ is equal to 0 yet allowing for all other variables including $\alpha_{t-1}$ to be different from 0 . Thus, if $\varepsilon_{t}^{e o p}>0$, namely if the currency depreciates over time, it must be the case that $e_{t}^{a v g} / e_{t}^{e o p}<1$ and so $i_{t}^{i y x r}<i_{t}^{\text {no } i y x r}$. It is the fact that the ratio $e_{t}^{a v g} / e_{t}^{e o p}$ moves inversely with $\varepsilon_{t}^{e o p}$ that brings this relation between the valuation-adjusted effective rates. However, for "sufficiently large" values of $\alpha_{t}$, this relation between these effective rates may revert.

${ }^{16}$ See Escolano and others (2017) and Mauro and Zhou (2020) for discussions on the rationale behind negative interest rate-growth differentials.
} 
differentials, the primary balance and other net debt-creating flows, the next subsections discuss how these valuation effects affected public debt dynamics over time using this dataset.

\section{Evidence on stock-flow adjustment, debt projections and debt-stabilizing primary balances}

The stock-flow adjustment term due to intra-year exchange rate fluctuations as percent of GDP can be computed using $s f_{t}=\frac{\left(e_{t}^{e o p}-e_{t}^{a v g}\right)}{e_{t}^{e o p}}\left(\alpha_{t} d_{t}-\alpha_{t-1} d_{t-1} \frac{\left(1+\varepsilon_{t}^{e o p}\right)}{\left(1+g_{t}\right)\left(1+\pi_{t}\right)}\right)$ (see footnote 10), where $d_{t}$ and $d_{t-1}$ reflect the stock of debt as reported in WEO for the country/year under consideration. Table 3 does so, showing that the average stock-flow adjustment term is 0.02 percent of GDP for the full sample, with slightly larger figures for the UMICs and LMICs country groups ( 0.03 and 0.02 percent of GDP, respectively). This term, however, could take sizeable figures in some specific cases. In fact, for the sub-sample of country/year observations with large nominal exchange rate depreciations, namely above the $90^{\text {th }}$ and $99^{\text {th }}$ percentile of the full sample, the average stock-flow adjustment term reached 0.2 and 1.2 percent of GDP, respectively (Table 3). Ignoring this term could then lead to inaccuracies at the time of projecting public debt, and the associated policy-relevant indicators.

Table 3: Estimations of stock-flow adjustment due to intra-year exchange rate changes (sample 2008-19, in percent of GDP)

\begin{tabular}{lcccccc}
\hline & \multirow{2}{*}{$\begin{array}{c}\text { No of } \\
\text { countries }\end{array}$} & Obs & \multicolumn{4}{c}{ Stock-flow adjustor } \\
\cline { 4 - 7 } & 28 & 161 & 0.00 & 0.07 & -0.28 & 0.47 \\
\hline HICs & 35 & 231 & 0.03 & 0.31 & -0.99 & 3.53 \\
UMICs & 19 & 182 & 0.02 & 0.11 & -0.25 & 0.81 \\
LMICs & 82 & 574 & 0.02 & 0.21 & -0.99 & 3.53 \\
Full sample & 5 & 5 & -0.03 & 0.09 & -0.14 & 0.09 \\
Nom depr below 1st pctile & 35 & 57 & -0.03 & 0.07 & -0.33 & 0.19 \\
Nom depr below 10th pctile & 29 & 57 & 0.20 & 0.62 & -0.99 & 3.53 \\
Nom depr above 90th pctile & 5 & 5 & 1.22 & 1.59 & -0.13 & 3.53 \\
Nom depr above 99th pctile & & & & & & \\
\hline
\end{tabular}

Note: Countries' group income classification based on that of World Bank as of 2017. Stock-flow adjustment computed on a country/year basis with the formula indicated in footnote 10.

Source: Author's calculations based on IMF's WEO and MAC DSA datasets.

To fully understand the implications of intra-year exchange rate valuation effects on public debt projections, it is useful to undertake the following counter-factual exercise. Let us assume that initially public gross debt levels are exactly as reported in WEO, April 2020 release, regardless of whether intra-year exchange rate fluctuations are considered, i.e., $d_{t-1}^{\text {iyxr }}$ and $d_{t-1}^{\text {no iyxr }}$ as defined in (6) and (7) are initially the same, say in 2007. However, for the period 2008-19, it is assumed that observed gross public debt levels as reported in WEO followed the data generating process with intra-year valuation effects as defined in (6). This 
allows us to generate an implicit time series for other net debt-creating flows, $o f_{t}$, for the period 2008-19. ${ }^{17}$

With $o f_{t}$ at hand, it is then possible to compare the difference in public debt stocks projected one year ahead using (6) or (7) starting from an initial stock of debt such that $d_{t-1}^{\text {iyxr }}=$ $d_{t-1}^{\text {no iyxr }}$. By construction, $d_{t}^{i y x r}$ projected using (6) will always coincide with the debt stocks reported in WEO. That way the difference $d_{t}^{i y x r}-d_{t}^{\text {no_iyxr }}$ would fully reflect the relevance of intra-year exchange rate fluctuations for projecting debt one year ahead. Similarly, the difference $D S P B_{t}^{i y x r}-D S P B_{t}^{n o \_i y x r}$ would reflect the full impact of intra-year exchange rate valuation effects in assessing the primary balance needed to stabilize debt at the previous year debt level.

Results of this counter-factual exercise are shown in Figures 3 and 4, below, focusing only on the sub-samples with small (below $1^{\text {st }}$ percentile of the full sample) and large (above $99^{\text {th }}$ percentile of the full sample) nominal exchange rate depreciations. The scatter plots show the estimated values of the stock-flow adjustment and the difference in either debt levels, $d_{t}^{i y x r}-d_{t}^{\text {no_iyxr }}$ (Figure 3), or debt stabilizing primary balances, $D S P B_{t}^{i y x r}-D S P B_{t}^{\text {no_iyxr }}$ (Figure 4). Observe that it is assumed $d_{t-1}^{i y x r}=d_{t-1}^{\text {no_iyxr }}$ one year before the country/year episodes identified in Figures 3 and 4. Also, and to further clarify the sources of the differences in debt projections, Appendix B shows the full list of the countries shown in Figures 3 and 4, identifying in full the contributors of their respective debt changes.

Figure 3, Panel B and Appendix B show that for those countries that experienced large nominal depreciations during 2008-19, the stock-flow adjustment term was on average significant at around 1.2 percent of GDP. Thus, ignoring these intra-year valuation effects would have led to an underestimation in debt projections by about 0.9 percentage points (ppts) of GDP. In some cases, differences in debt projections could have been even larger, such as Argentina in 2018 (1.6 ppts of GDP) or Surinam in 2016 (3.3 ppts of GDP). On the contrary, in those countries that experienced nominal depreciations below the $1^{\text {st }}$ percentile, the stock-flow adjustment term was generally low or even negative, involving only more minor miscalculations in debt projections (Figure 3, Panel A and Appendix B).

Sizable figures also arise when assessing differences in the primary balance needed to stabilize debt at the previous-year level (DSPB). Again, for those countries that experienced large nominal exchange rate depreciations, the stock-flow adjustment term is relevant, and thus the inaccuracies in estimating the DSPB would have led to an overestimation of about 1.5 ppts of GDP on average (Figure 4, Panel B and Appendix B), with differences that are

${ }^{17}$ That is, from (6) it is possible to derive for every country/year observation $o f_{t}=d_{t}^{i y x r}\left(1-\alpha_{t} \gamma_{t}\right)-$ $\left(\frac{1+i_{t}^{i y x r}}{\left(1+g_{t}\right)\left(1+\pi_{t}\right)}\right)\left(1-\alpha_{t} \gamma_{t}\right) d_{t-1}^{i y x r}+p b_{t}$, where $d_{t}^{i y x r}$ is exactly the gross debt level reported by WEO for every country during 2007-19. Note that when assessing observed data, the term $o f_{t}$ would subsume a pure residual, capturing also non-identifiable debt-creating flows arising from accounting issues (e.g., cash vs accrual accounting), cross-exchange rate fluctuations when more than one foreign currency is involved, intra-year exchange rate fluctuations that occur at a lower frequency not properly accounted for in the annual frequency considered here, etc. 
even larger for say Argentina in 2018 (-4 ppts of GDP) or Angola in 2018 (-2.2 ppts of GDP).

Figure 3: Public debt projections and stock-flow adjustment
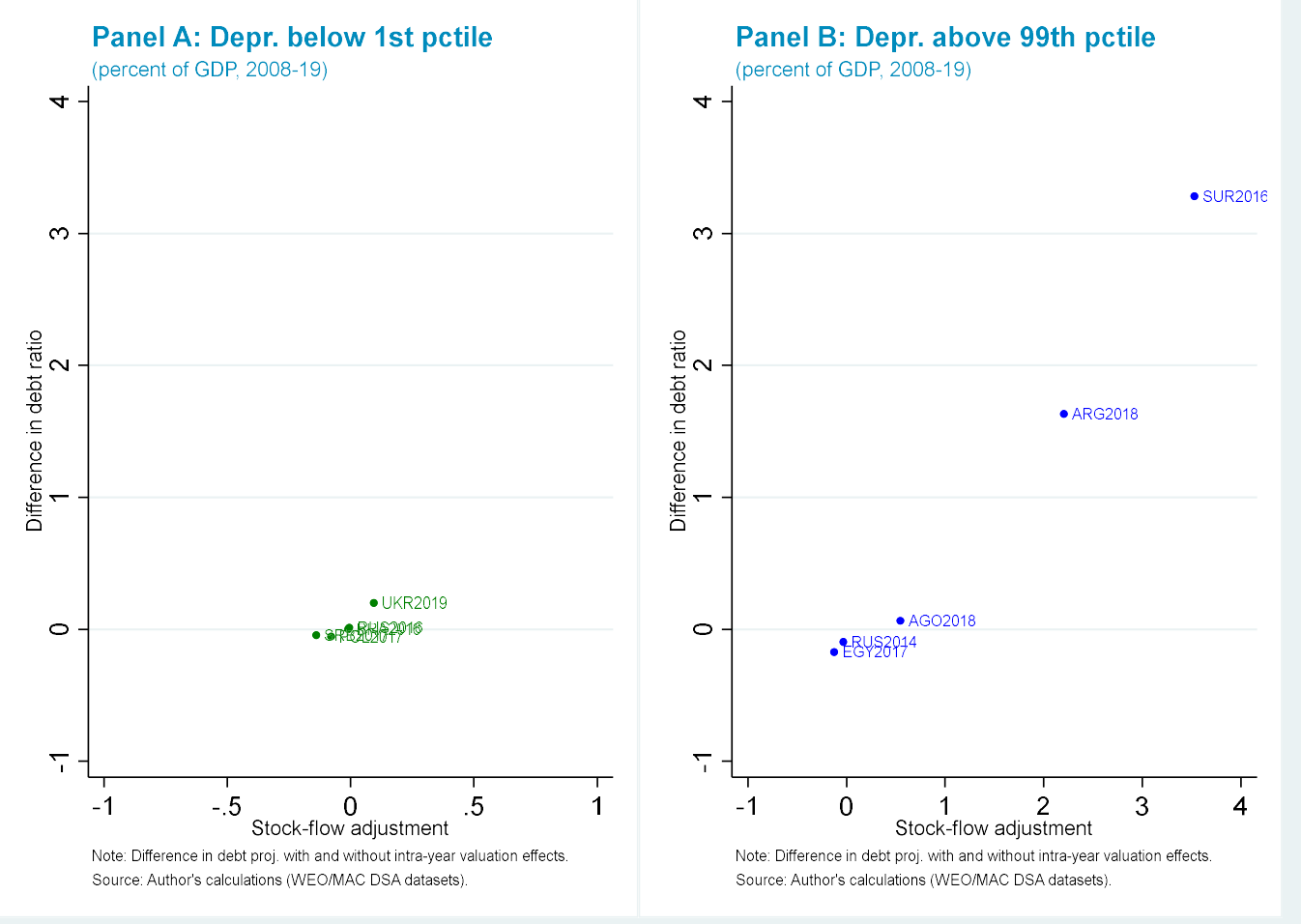

The intuition as of why public debt could be simultaneously underestimated while the debtstabilizing primary balance overestimated when intra-year exchange rate fluctuations are ignored, is as follows. Consider the case of Argentina in 2018. Since the country experienced a large currency depreciation in 2018, it followed that $e_{t}^{a v g} / e_{t}^{e o p}<1$. Typically, $e_{t}^{\text {avg }} / e_{t}^{e o p}<$ 1 in countries experiencing nominal exchange rate depreciations. From Tables 5 and 6 , the automatic debt dynamics portion of the change in debt is lower in Argentina when intra-year valuation effects are included (recall that it is assumed that in 2017 debt levels are the same), due to the lower interest rate-growth differential. However, the contribution of the primary deficit and other net debt-creating flows to the change in debt is higher, since these flows add new debt, including that denominated in foreign currency, at the lower exchange rate $e_{t}^{a v g}$ relative to $e_{t}^{e o p}$. The overall net effect is a higher change in the debt stock projected in Argentina in 2018 if intra-year valuation effects are included. Now, if one is asking what would have been the primary balance needed in 2018 to stabilize debt at the 2017 level, the answer, for the reason explained before, is that it should have been lower relative to a case where intra-year exchange rate fluctuations are ignored. This occurs since the flow primary surplus would have reduced a larger amount of debt through its conversion to the foreign currency at the lower exchange rate $e_{t}^{a v g}$ relative to $e_{t}^{e o p}$. 
Figure 4: Debt-stabilizing primary balance and stock-flow adjustment
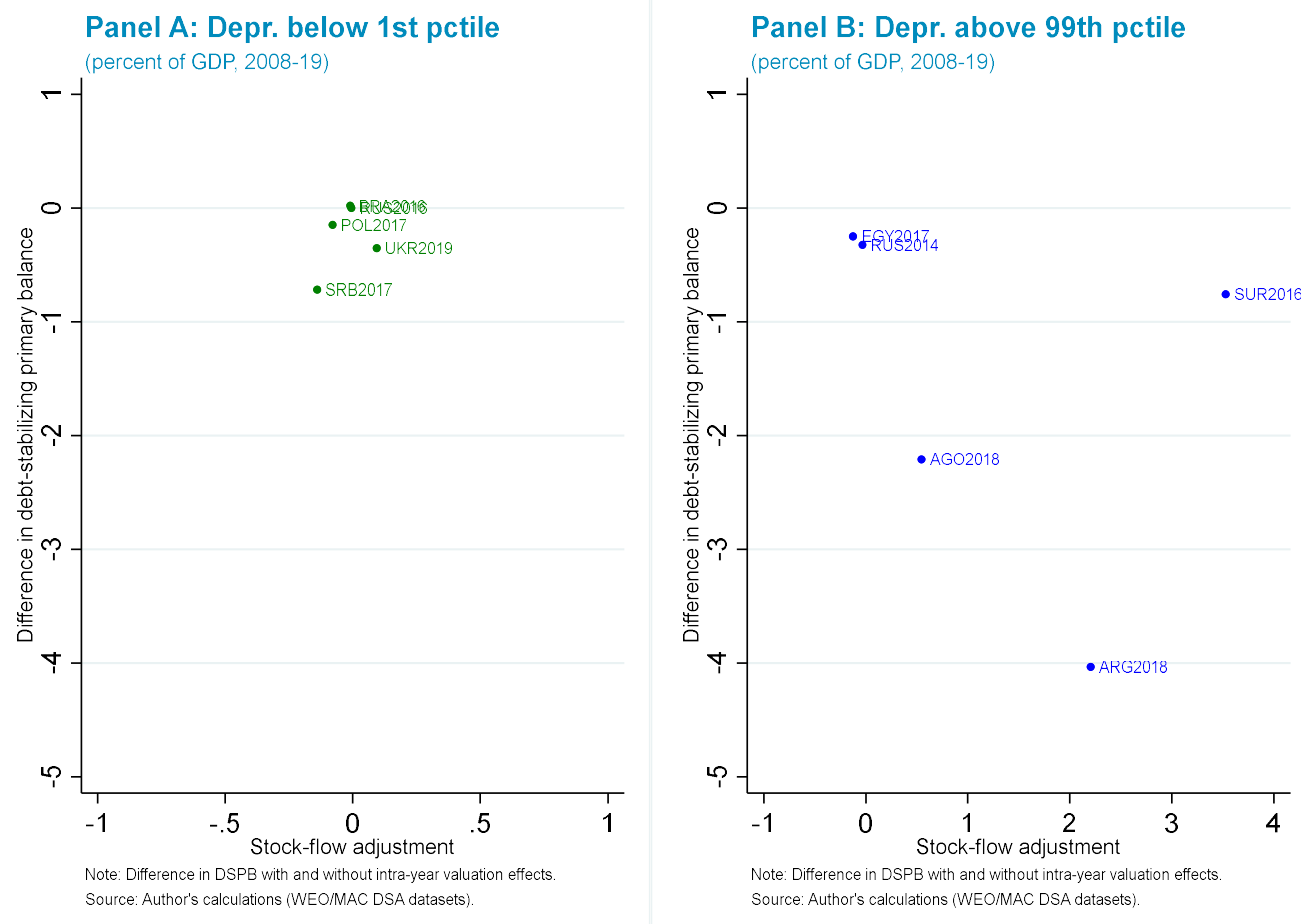

\section{CONCLUDING REMARKS}

Since the public sector often incurs liabilities denominated in foreign currency, as observed in many emerging and developing countries, periods of heightened exchange rate volatility could lead to substantial revaluations of those liabilities when these are measured in local currency and/or as a share of GDP. Thus, a careful consideration of how exchange rate fluctuations affect foreign currency denominated flows and stocks is critical for assessing how public debt evolves over time.

This paper lays out the basic above-the-line equation to measure the evolution of public sector debt, considering that debt-related stocks and flows denominated in foreign currency should be converted to local currency using the end-of-period and the average exchange rates, respectively, as envisaged in public finance manuals. This accounting consideration, somewhat abstracted away in the related literature (e.g., Croce and JuanRamón, 2003; IMF, 2013; Escolano and others, 2017), gives rise to a stock-flow adjustment term stemming from intra-year exchange rate fluctuations. The paper then shows that this type of exchange rate valuation effect may have an impact on the computation of public debt over time, the interest rate-growth differential and the debtstabilizing primary balance in non-negligible ways, particularly in cases with large exchange rate depreciations. Moreover, the inclusion of this often-ignored stock-flow adjustment term is critical to accurately project public debt levels and any associated policy indicator that could in turn inform about the risk of debt distress. 
A relevant extension of the paper could be to increase the coverage of the empirical analysis to also include low-income countries to quantify, in a larger sample, the size of this stockflow adjustment term and its impact on public debt projections. Another important strand of future work could involve the assessment of how intra-year exchange rate fluctuations might affect medium-term debt targets, particularly in those countries that have experienced large deviations between the average and the end-of-period exchange rates in their recent history. This could be particularly timely in those economies envisaging consolidation paths to be spread out over time, since assessing intra-year exchange rate valuation effects may help determine more accurately which are the fiscal paths that are consistent with a specific medium-term debt objective in these countries.

\section{APPENDIX}

\section{A. Valuation-adjusted nominal effective interest rates}

This appendix summarizes the mean values of the effective nominal interest rates defined as $i_{t}^{i y x r}, i_{t}^{\text {no_iyxr }}$ and $i_{t}^{\text {fisc }}$ (the latter is derived according to the formula in footnote 9).

Table 4: Estimations of nominal effective interest rates (average 2008-19, percent)

\begin{tabular}{|c|c|c|c|c|c|}
\hline & $\begin{array}{c}\text { No of } \\
\text { countries }\end{array}$ & Obs & $\begin{array}{l}\text { i_iyxr } \\
\text { Mean }\end{array}$ & $\frac{\text { i_no_iyxr }}{\text { Mean }}$ & $\frac{i \text { fisc }}{\text { Mean }}$ \\
\hline HICs & 28 & 161 & 5.30 & 5.31 & 4.81 \\
\hline UMICs & 35 & 231 & 7.83 & 7.89 & 5.59 \\
\hline LMICs & 19 & 182 & 7.83 & 7.88 & 5.53 \\
\hline Full sample & 82 & 574 & 7.12 & 7.16 & 5.35 \\
\hline Nom depr below 1st pctile & 5 & 5 & -0.52 & -0.52 & 6.40 \\
\hline Nom depr below 10th pctile & 35 & 57 & 2.36 & 2.30 & 5.54 \\
\hline Nom depr above 90th pctile & 29 & 57 & 19.42 & 19.66 & 6.67 \\
\hline Nom depr above 99th pctile & 5 & 5 & 44.30 & 45.03 & 7.83 \\
\hline
\end{tabular}

Note: Countries' group income classification based on that of World Bank as of 2017. Effective interest rates computed on a country-by-country basis using (4), (5) and footnote 9 , and averaged across the different samples reported in the table.

Source: Author's calculations based on IMF's WEO and MAC DSA datasets.

Table 4 shows that $i_{t}^{i y x r}<i_{t}^{\text {no_iyxr }}$, with the only exception of those countries experiencing nominal depreciations below the $1^{\text {st }}$ percentile, which is consistent with the fact that most countries experienced nominal exchange rate depreciations during the sample period or, put it differently, that the exchange rate ratio has been $e_{t}^{a v g} / e_{t}^{e o p}<1$ for the average country (see Table 1). Table 4 further shows that $i_{t}^{i y x r}$ tends to be particularly lower than $i_{t}^{\text {no } i y x r}$ for the sub-sample of countries experiencing depreciations above the $90^{\text {th }}$ or the $99^{\text {th }}$ percentile of the full sample. This table also illustrates that average nominal effective interest rates that can be retrieved from fiscal statements, $i_{t}^{\text {fisc }}$, cannot be used directly to assess public debt dynamics, unless these are properly adjusted for exchange rate valuation effects. 


\section{B. Decomposition of changes in the public debt to GDP ratio}

This annex presents a full decomposition of the key drivers of public debt changes to better understand the implications of intra-year exchange rate valuation effects to project public debt. From (6), it is possible to identify three additive contributors of debt changes, namely: (i) the effect of the interest rate-growth differential on the previous period stock of debt (sometimes called automatic debt dynamics); (ii) the effect of the primary balance; and (iii) the effect of other net debt-creating flows. The underlying analytical expressions of each contributor are indicated below:

$$
\begin{aligned}
& d_{t}^{i y x r}-d_{t-1}^{i y x r}=\left(\frac{1+i_{t}^{i y x r}}{\left(1+g_{t}\right)\left(1+\pi_{t}\right)}-1\right) d_{t-1}^{i y x r}-\frac{1}{1-\alpha_{t} \gamma_{t}} p b_{t}+\frac{1}{1-\alpha_{t} \gamma_{t}} o f_{t} . \\
& \text { Automatic debt dynamics }
\end{aligned}
$$

Instead, when intra-year valuation effects are abstracted away, these contributors to public debt changes, from (7), take the form:

$$
\begin{aligned}
d_{t}^{\text {no_iyxr }}-d_{t-1}^{n o \_i y x r} & =(\underbrace{\left.\frac{1+i_{t}^{n o \_} i y x r}{\left(1+g_{t}\right)\left(1+\pi_{t}\right)}-1\right) d_{t-1}^{n o i} i y x r}-p b_{t}+o f_{t} \\
\text { Automatic debt dynamics } & \begin{array}{l}
\text { Contribution of } \\
\text { primary balance }
\end{array}
\end{aligned}
$$

Observe that the stock-flow adjustment term can also be estimated using the formula presented in footnote 10. Adding this stock-flow adjustment term to (13) provides an almost identical quantification of the annual change in debt ratios as identified in (12). However, to recover exactly the change in debt that could be obtained with (12), the nominal effective interest rate $i_{t}^{\text {no_iyxr }}$ would need to be re-defined as,

$$
\hat{\imath}_{t}^{i y x r}=\alpha_{t-1}\left(1+i_{t}^{f} e_{t}^{a v g} / e_{t}^{e o p}\right)\left(1+\varepsilon_{t}^{e o p}\right)+\left(1-\alpha_{t-1}\right)\left(1+i_{t}^{d}\right)-1 .
$$

It stands out that the key difference between $\hat{\imath}_{t}^{i y x r}$ and $i_{t}^{\text {no_iyxr }}$ is the fact that $\hat{l}_{t}^{i y x r}$ includes intra-year exchange rate differences, $e_{t}^{a v g} / e_{t}^{e o p}$, whereas $i_{t}^{\text {no_iyxr }}$ does not (i.e., compare (5) and (14)).

Tables 5 and 6 summarize the debt levels projected with and without intra-year valuation effects, $d_{t}^{i y x r}$ and $d_{t}^{\text {no_iyxr }}$, changes in debt ratios, $d_{t}^{i y x r}-d_{t-1}^{i y x r}$ and $d_{t}^{\text {no_iyxr }}-d_{t-1}^{\text {no_iyxr }}$, and debt-stabilizing primary balances, $D S P B_{t}^{i y x r}$ and $D S P B_{t}^{\text {no_iyxr }}$, for the countries/years shown in Figures 3 and 4 . The contributors to annual debt changes with and without intrayear valuation effects (i.e., automatic debt dynamics, contribution of the primary balance and contribution of other net debt-creating flows) are defined as in (12) and (13) in Tables 5 and 6 , respectively. Table 5 also presents the estimations of the stock-flow adjustment term. This confirms that intra-year exchange rate valuation effects could lead to sizable discrepancies in 
terms of debt projections in countries exposed to large currency fluctuations and foreign currency debt (i.e., a large stock-flow adjustment term), with relevant implications at the time of identifying the contributors of debt changes and/or measuring policy relevant indicators such as the debt stabilizing primary balance.

Table 5: Debt projections drivers with intra-year exchange rate fluctuations (percent of GDP)

\begin{tabular}{|c|c|c|c|c|c|c|c|}
\hline & $\begin{array}{l}\text { Stock of gross } \\
\text { public debt }\end{array}$ & $\begin{array}{l}\text { Change in } \\
\text { gross public } \\
\text { debt }\end{array}$ & $\begin{array}{l}\text { Automatic } \\
\text { debt } \\
\text { dynamics }\end{array}$ & $\begin{array}{l}\text { Contribution } \\
\text { primary } \\
\text { deficit }\end{array}$ & $\begin{array}{l}\text { Contribution } \\
\text { other flows }\end{array}$ & $\begin{array}{l}\text { Stock-flow } \\
\text { adjustment }\end{array}$ & DSPB 1/ \\
\hline \multicolumn{8}{|c|}{ Nom. Depr. < 1st pctile } \\
\hline BRA2016 & 78.31 & 5.74 & 4.85 & 0.27 & 0.61 & -0.01 & 5.48 \\
\hline POL2017 & 50.60 & -3.63 & -4.90 & -0.10 & 1.36 & -0.08 & -3.62 \\
\hline RUS2016 & 14.85 & -0.44 & -0.36 & 2.69 & -2.76 & -0.01 & -3.21 \\
\hline SRB2017 & 58.73 & -10.15 & -8.88 & -3.68 & 2.41 & -0.14 & -6.90 \\
\hline UKR2019 & 50.12 & -10.47 & -8.20 & -0.95 & -1.32 & 0.09 & -10.02 \\
\hline \multicolumn{8}{|c|}{ Nom. Depr. > 99th pctile } \\
\hline AGO2018 & 89.00 & 19.74 & 12.42 & -7.60 & 14.92 & 0.54 & 24.18 \\
\hline ARG2018 & 86.06 & 28.95 & 16.43 & 2.81 & 9.71 & 2.20 & 21.02 \\
\hline EGY2017 & 103.16 & 6.32 & -9.40 & 2.25 & 13.47 & -0.13 & 4.02 \\
\hline RUS2014 & 15.14 & 2.79 & 1.19 & 0.44 & 1.15 & -0.03 & 2.15 \\
\hline SUR2016 & 76.07 & 32.72 & 12.90 & 7.38 & 12.44 & 3.53 & 22.21 \\
\hline
\end{tabular}

Table 6: Debt projections and drivers without intra-year exchange rate fluctuations (percent of GDP)

\begin{tabular}{|c|c|c|c|c|c|c|c|}
\hline & $\begin{array}{l}\text { Stock of gross } \\
\text { public debt }\end{array}$ & $\begin{array}{l}\text { Change in } \\
\text { gross public } \\
\text { debt }\end{array}$ & $\begin{array}{l}\text { Automatic } \\
\text { debt } \\
\text { dynamics }\end{array}$ & $\begin{array}{l}\text { Contribution } \\
\text { primary } \\
\text { deficit }\end{array}$ & $\begin{array}{l}\text { Contribution } \\
\text { other flows }\end{array}$ & $\begin{array}{l}\text { Stock-flow } \\
\text { adjustment }\end{array}$ & DSPB 1/ \\
\hline \multicolumn{8}{|c|}{ Nom. Depr. < 1st pctile } \\
\hline BRA2016 & 78.31 & 5.73 & 4.85 & 0.27 & 0.62 & - & 5.46 \\
\hline POL2017 & 50.66 & -3.58 & -4.88 & -0.10 & 1.40 & - & -3.48 \\
\hline RUS2016 & 14.84 & -0.45 & -0.37 & 2.76 & -2.84 & - & -3.21 \\
\hline SRB2017 & 58.77 & -10.11 & -8.76 & -3.92 & 2.57 & - & -6.19 \\
\hline UKR2019 & 49.91 & -10.67 & -8.28 & -1.00 & -1.39 & - & -9.67 \\
\hline \multicolumn{8}{|c|}{ Nom. Depr. > 99th pctile } \\
\hline AGO2018 & 88.93 & 19.67 & 13.20 & -6.72 & 13.20 & - & 26.39 \\
\hline ARG2018 & 84.42 & 27.31 & 17.24 & 2.26 & 7.81 & - & 25.05 \\
\hline EGY2017 & 103.33 & 6.49 & -9.03 & 2.22 & 13.30 & - & 4.27 \\
\hline RUS2014 & 15.23 & 2.88 & 1.42 & 0.41 & 1.06 & - & 2.48 \\
\hline SUR2016 & 72.79 & 29.43 & 12.06 & 6.47 & 10.91 & - & 22.97 \\
\hline
\end{tabular}




\section{REFERENCES}

Croce, Enzo and Hugo Juan-Ramón, 2003, “Assessing Fiscal Sustainability: A CrossCountry Comparison,” IMF Working Paper WP/03/145.

Escolano, Julio, Anna Shabunina, and Jaejoon Woo, 2017, “The Puzzle of Persistently Negative Interest-Rate-Growth Differentials: Financial Repression or Income Catch-Up?," Fiscal Studies, 38:2, pp. 179-217.

IMF, 2011. "Public Sector Debt Statistics: Guide for Compilers and Users," International Monetary Fund.

IMF, 2013, "Staff Guidance Note for Public Debt Sustainability Analysis in Market-Access Countries," International Monetary Fund, https://www.imf.org/external/np/pp/eng/2013/050913.pdf.

IMF, 2018, "Guidance Note on the Bank-Fund Debt Sustainability Framework for Low Income Countries," International Monetary Fund, https://www.imf.org/en/Publications/Policy-Papers/Issues/2018/02/14/pp122617guidance$\underline{\text { note-on-lic-dsf }}$

Mauro, Paolo and Jing Zhou, 2020, "r-g<0: Can We Sleep More Soundly," IMF Working Paper WP/20/52. 